HEROES AND MARTYRS OF QUALITY AND SAFETY

\title{
Public opinion is our supreme court: D W Cathell MD, The Physician Himself
}

\section{Neuhauser}

D aniel Webster Cathell MD (1839-1925) began writing his book "The Physician Himself" in 1882 to help new physicians in America prosper. His book was so popular that it was in its tenth edition in 1892, last revised in 1922 and republished in 1931 .

In those days, before the reforms in American medical education driven by the Flexner report of 1910, it was easy to become a physician-many men did so, but only a few prospered in this competitive world of private practice. These struggling practitioners were Cathell's readers. Cathell wrote so well it is best to quote him directly.

In 1890 he wrote: "The standard has fallen lower and lower, until we have at last reached a point at which the ... brainless bumpkin ... who is following the plow ... thinks he can find a place where he can be metamorphosed into an MD tomorrow and that a sign or doorplate with his name (and the prefix Doctor) on it and a buggy at his door is about all that is necessary." (1890, page 9)

At the court of public opinion Cathell said the doctor had to behave with dignity, look the part, and show himself properly to his hoped for patients. In 1890, when home visits were at the center of practice, the doctor either walked or went by horse to see his patients.

"If you unfortunately have a bony horse and a seedy looking ... buggy, do not let them stand in front of your office for hours at a time, as if to advertise your poverty, lack of taste or paucity of practice." (1890, page 22 )

By 1922 Cathell was recommending a car which, unlike the buggy horses, did not get tired going up hill.

"Clean hands, well-shaved face or neatly trimmed beard, unsoiled shirt and collar, unimpeachable hat, polished boots, spotless cuffs, well-fitting gloves; fashionable, well made clothing of fine texture, cane, sun-umbrella, neat office jacket ... indicate gentility and self respect."

"The majority of people will employ a well-dressed medical man with clean genteel appearance and manners; always neat but never gaudy. They will accord him more confidence, and willingly pay to him larger bills; even though he may have a homely figure and a baboon-face." (1931, page 27)

In the doctor's office, diplomas and "modest size busts or statues of our great medical heroes are ... in excellent taste", as is a nice book case with medical books in it (1931, pages 11-12), "but display no miniature museum of sharks' heads, stuffed alligators, tortoise-shells, impaled butterflies, miniature ships, mummies, snakes, ... tape worms, devil-fish or any thing else that will advertise you in any light other than that of an educated and cultivated physician."

In that era "A knowledge of Latin to a limited extent is of inestimable value. Employ some scholar to teach you at least as much of the elements of Latin as you need in writing prescriptions, etc. You can get one at a small cost by advertising anonymously in any daily paper." (1931, page 51)

The physician is a public figure about town. Don't be seen "loitering around drug-stores, hotel-lobbies, saloons, club-rooms, cigar-stores, billiard-parlors, barber-shops, corner-groceries, moving pictures etc with 'splendid fellows' who love doing nothing ..." (1931, page 15)

In those days it was called the doctor's bed side manner.

"Never ask the age of a patient more than once during attendance on his case. Take care also neither to ask any questions twice at the same visit nor to do anything else that would indicate lack of memory, lack of interest or incompetence." (1931, page 211)

"It is very pleasing to the sick to be allowed to tell in their own way whatever they deem important for you to know. Allow every one a fair hearing, and, even though their long statements are tedious, do not abruptly cut them short, but endure them and listen to them with respectful attention." (1890, page 44)

"... a bold, prompt act, that strikes the right nail on the head, done with unwavering steadiness of mind and nerve, if successful, often leads almost to idolatry ..." (1890, page 44)

"Act toward timid children and nervous patients so as to remove all dread of your visits. Avoid a set sad countenance, solemn and formal or funereal solemnity of visage and manner, as it would give rise to thoughts of crape, hearse, undertaker, and grave, and to dread of you, especially if you accompany it with a corresponding mode of dress. If you have a lengthened visage, or your air and movements are naturally awkward, sombre, or singular, offset them by cheerfulness, suitable dress, etc." (1890, page 46)

A public appearance of cheerfulness, hope, kindness, manners, purity of mind and politeness will create respect, confidence, reputation, and popularity. For success, combine these traits with medical knowledge soundly applied and with out error. Speaking of errors:

"Never write a prescription carelessly. Legibility is the first requirement, neatness the second, Cultivate the habit of scrutinizing every thing you write after it is written, to assure yourself that there is neither omission nor mistake and sign your name or initials to every prescription, but not until you have satisfied yourself that it is as intended. Mistakes are seldom discovered unless at the moment of their occurrence." (1890, pages 178-9)

Cathell wrote about good business practices. Be paid in cash, not credit. The doctor should manage his own personal health by not working to exhaustion. The measured outcomes of "professional tact and business sagacity"(1890, page 291) were no debts and money in the bank, paid promptly by grateful patients who could easily seek care elsewhere.

"There are two kinds of reputation a physician may acquire-a popular one with the people and a purely professional one with his brethren. These are often based on entirely different grounds and are usually no measure of each other ..." Try to possess both." (1890, page 39)

Unlike Cathell who spoke to the average struggling practitioner, academic physicians focused on specialization, research, and peer reputation. Their work was in large city hospitals and not the small towns. Many of them scorned the court of public opinion. After all, what do patients know about the science of medicine? These academics taught future generations of physicians. Flexner's reforms closed medical schools which catered to "boys from the plow", reduced the number of physicians and thereby reduced 
competition. After the 1940s, more and more physicians could ignore the court of public opinion. In this climate, Cathell's non-academic voice became a whisper and then was lost and forgotten.

Cathell practised in Baltimore, Maryland in the same city and time when Johns Hopkins Medical School was transforming American academic medicine. The best known leader of this new scientific era was (later Sir) William Osler who presided over the court of medical peer opinion. He read Cathell's book and had this two edged critique of it.

"... while there are plenty of other men who can write other and greater books, there are not three others among us who possess the experience, the industry and the ability to write such a book on this subject." (1931, Introduction)

We know very little about Daniel Webster Cathell. He was born in 1839 in New Hope, Maryland and went to public high school in Baltimore. He graduated from the State University of New York Downstate College of Medicine, Brooklyn, New York in 1865 as an allopathic physician. He started to practice in Baltimore in that same year and remained there throughout his life. In this era before formal medical specialization, he was also a professor of pathology at the College of Physicians and Surgeons of Baltimore. He died at the age of 86 at the Church Home and Infirmary on 1 May 1925. ${ }^{23}$

Dear reader, do not make D W Cathell a martyr due to neglect and high seated scorn. He has an important message about quality for us. Pay deep and close attention to how patients perceive the physician and the office visit. How are trust, respect, and confidence created? "Character reading is a science." (1931, page 290) How are both the needs and the wishes of patients and families met? Minor details can make a great difference in public perception.
"Bear, therefore, the greatness of your trust, and the responsibility and glory of your almost divine mission, ever in your mind. Remember at all times that every phase of your conduct, every word you utter, every look, every nod of your head, tremble of your tongue, quiver of your lips, wink of your eye, and shrug of your shoulders, will be observed and considered. Therefore strive to make your manner and your methods as faultless as possible ... observe punctuality and system in attending all who place themselves under your care, and strive to do the greatest absolute good for each and every one of your patients, that you may merit to be called A MODEL PHYSICIAN." (1890, page 290)

Cathell is right: public opinion is the supreme court and the court of peer prestige exists only by gracious permission and sufferance. If so, quality of care means paying very, very close attention to the details of this trust and mission.

Correspondence to: Professor D Neuhauser, Department of Epidemiology and Biostatistics, Case School of Medicine, Case Western Reserve University, Cleveland, OH 44106-4945, USA; dvn@case.edu

\section{REFERENCES}

1 Cathell DW. The Physician Himself, Incomplete publishing history. First edition 1882: 194, Cushings and Bailey, Baltimore, Second edition 1882:208. Third edition, 1883. Fourth edition, 1885. Seventh edition, 1886. Ninth Edition, Revised and Enlarged, 1889 and 1890:298. F A Davis, Philadelphia (cited here). Tenth Edition 1892:343. Tenth Editions Revised, 343, 1893, 1896 1897, 1898, 1899 and 1900. Eleventh Edition, 1902. Eleventh Edition, enlarged "with the help of his son William T Cathell MD" 1903, 1904. The Twentieth Century Edition, 1905:411, 1906, 1908, 1911. Twelfth and Final Edition, 1913:407. Crowning Edition, 359, 1922, 1924, 1925, 1926 , 1931 (cited here). Reprinting of the second edition Ayer Co, 1972, ISBN 0405039417. Facsimile Edition, Cushings and Bailey, paperback, 1990

2 Hafner A, ed. Dictionary of deceased American physicians 1804-1929. Chicago: American Medical Association, 1993;1:262.

3 Anon. Obituary. JAMA 1925;84:1513. 